\title{
RESENHA
}

\section{Errar é humano}

Nesta obra, Christian Morel - executivo de uma grande empresa automobilística francesa - dedica-se à compreensão do intrincado processo que leva à tomada de decisões absurdas: os erros radicais e persistentes cometidos pelas pessoas contra os objetivos que fixaram para si mesmas.

Por Allan Claudius Queiroz Barbosa CEPEAD-UFMG

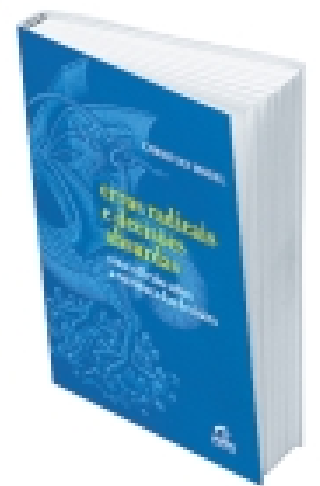

Erros radicais e decisões absurdas: uma reflexão sobre a estrutura das decisões Christian Morel Editora Campus
$\mathbf{A}$ administração de empresas está cheia delivros voltados paraum público ávido por soluções embaladas em linguagem mística e de autoajuda. A questão foi registrada com precisão pelos jornalistas da revista britânica The Economist, John Micklethwait e Adrian Wooldridge, em "Os bruxos da administração" (Campus, 1998).

A enorme força mercadológica que move a disseminação quase epidêmica desse tipo de literatura (se é que a podemos denominar literatura) acaba criando situações estranhas: enquanto obras defácil apelo e baixa consistência ganham destaque nas prateleiras e nas listas de best-sellers, outras, elaboradas com rigor e cuidado, são relegadas ao esquecimento. Com isso, estas obras acabam restritas a grupos de obstinados leitores com vocação detetivesca.

Esse parece ser o caso do livro de Christian Morel, recentemente lançado no Brasil. A obra ganhou em 2002, na França, um importante prêmio dado pela consultoria Mckinsey. Doutor em ciências políticas e diretor de recursos humanos da divisão de veículos comerciais da Renault, Morel foca sua atenção em "com- preender decisões estranhas: aquelas em que seus autores agem com insistência e de forma intensiva contra o objetivo a que eles mesmos se propuseram" (p. XIX).

0 livro está dividido em quatro partes. Na primeira, o autor exemplifica 0 que seriam essas decisões em diferentes segmentos, tais como na pilotagem aérea e marítima, na administração e até mesmo na vida cotidiana. Morel procura conceituar o que seria exatamente uma decisão absurda. Sua premissa éa de que, em uma decisão absurda, "existe um desacordo poderoso, uma contradição, uma desconexão considerável entre a ação empreendida eo objetivo perseguido" ( $p$. 34). Com isso, as decisões absurdas geram diferentes categorias de resultados, diferentes do objetivo pretendido.

$\mathrm{Na}$ segunda parte 0 autor trata dos processos de raciocínio que levam ao engano e à persistência do erro, novamente lançando mão dos exemplos práticos que destacou na primeira parte. Morel apresenta o que ele chama de "bricolagem cognitiva"; isto é, aquilo que se passou pela cabeça das pessoas envolvidas nas diferentes decisões absurdas dadas como exemplos. Segundo o autor, 
essa bricolagem "é formada por raciocínios extremamente simples, estranhos aos princípios do raciocínio do tipo científico, metódico, analítico ou dedutivo" (p. 60).

$\mathrm{N}$ a terceira parte $\mathrm{o}$ autor aborda os fenômenos coletivos, considerados como parte da explicação possível para uma decisão absurda. Aqui, os papéis do gerente, do especialista e do leigo são identificados, bem como suas ações. 0 autor observa que, nos casos estudados de erros radicais, os três papéis estão presentes, assim como cinco ações possíveis - produzir, solicitar, seguir, estar ausente e opor-se. Em um exercício de construção de modelos de decisões absurdas, Christian Morel propõe diferentes matrizes combinadas entre papéis, ações e sua aplicação. 0 autor ainda descreve a chamada "impermeabilidade dos erros" a correções por quem está de fora da situação.

Por fim, na quarta parte 0 autor afirma que as decisões podem ser absurdas porque seriam privadas de sentido, re discutindo seu conceito provisório de bricolagem apresentado na segunda parte. Conclui chamando atenção para a necessidade de uma explicação cognitiva, coletiva e teleológica (relativa ao modo como os seres humanos administram as finalidades) para a geração de decisões medíocres, verdadeiramente sem sentido.

Erros radicais e decisões absurdas aborda um tema recorrente da administração: tomar decisões está na essência do trabaIho gerencial. E traz à baila uma discussão sobre 0 absurdo das decisões, presente de maneira tão clara no cotidiano administrativo. Certamente essa reflexão a posteriori pode servir de exemplo de como não fazer. O u de lição, caso tenha sido cometido o erro.

Morel segue a trilha inaugurada há algumas décadas por pesquisadores e observadores do mundo corporativo interessados em ir além das aparências. Por trás de fachadas bem comportadas, muitas empresas são palcos turbulentos, cheios de personagens irracionais e eventos caóticos. Após a leitura, permanecerá certamente com o leitor a sensação de ter dado mais um passo para o entendimento desses estranhos aparatos presentes em quase todos os momentos de nossas vidas: as organizações.

Allan Claudius Queiroz Barbosa

Prof. do Departamento de Administração e do Centro de Pós-Graduação e Pesquisas em Administração da UFMG

E-mail: allan@ufmg.br 